
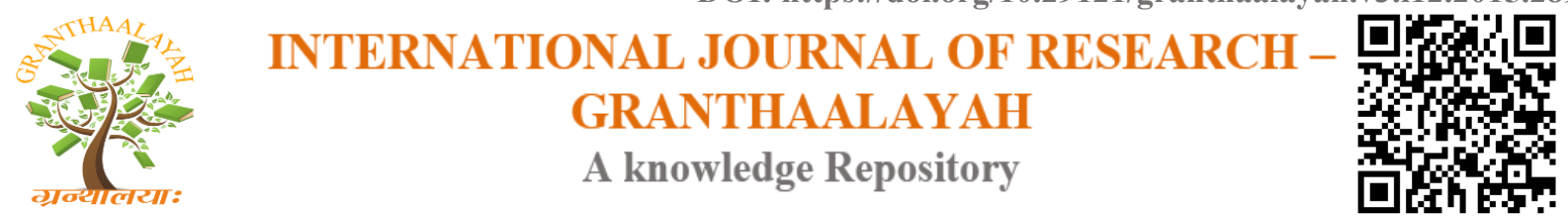

Management

\title{
CASE STUDY ON FAMILY MANAGED BUSINESS: WHEN \& WHY JOIN FAMILY BUSINESS?
}

\author{
Parimal Merchant ${ }^{* 1}$ \\ ${ }^{* 1}$ Professor \& Director, Global Family Managed Business Program, \\ S. P. Jain School of Global Management, INDIA
}

\begin{abstract}
Pramod, a self-made businessman is facing challenges in inducting his son Tarun in the business. Initially, the son has serious reservations about the business and does not want to join. But after failure in his own initiatives, eventually he reluctantly joins the family business. Over the years the business has doubled but profitability has declined. The relation between father and son were strained and it deteriorated further. Personally both of them are unhappy.
\end{abstract}

Keywords:

self-made businessman, family business.

Cite This Article: Parimal Merchant, "CASE STUDY ON FAMILY MANAGED BUSINESS: WHEN \& WHY JOIN FAMILY BUSINESS?" International Journal of Research - Granthaalayah, Vol. 3, No. 12(2015): 117-124. DOI:10.29121/granthaalayah.v3.i12.2015.2895

\section{INTRODUCTION}

Pramod, now aged 55, a commerce graduate started a business of processing polymers in Mumbai in 1978. His father was a broker in textile market and had a very small business. Pramod decided to learn the business with his uncle in the polymer industry. He initially started with trading and eventually in 1985, set up his own unit in Silvasa in Gujarat. By 1999 he had a turnover of Rs. 50 crores.

Pramod has a son Tarun. Tarun was not good at studies. He also did not take much interest in father's business. He maintained that his father's business is too small and he will start a new business ad make it big. He managed to complete his graduation. He tried to start a venture of his own but did not succeed. Eventually he decided to join the father's business in 1999 at the age of 22. He did not have any idea about the polymers. He started attending the office but had no clear responsibilities. As he observed his father he felt that his father was getting too much involved in niti-grity instead of appointing competent people and delegating the work. When he discussed this point, his father would explain that in this business it is necessary to be hands on. That way you will know all aspects of the business as well as respect from the employees. 
Pamod was not very happy with the attitude of his son of not getting in details. He tried several times to advise Tarun to get more actively involved in the business and take responsibilities. Tarun always had reasons to justify why he could not work effectively and believed that his father's style was wrong and it is because of that the business was still very small. He believed that given free hand he would grow the business very fast but Pramod would not give him free hand.

Eventually they had strained relationship between them. They avoided facing each other the communication within them was minimal.

Over the years, Tarun did get more involved in the business. He started taking the responsibilities, the business grew to nearly Rs. 100 crore but the profitability has drastically declined. The key people developed by Pramod have left the organisation as they found Tarun's demands unreasonable. Tarun did not have much firsthand experience in the business and as such could not come up with any innovation. There were some new product launched by Pramod and that saved the day. In the meantime the relations between the father-son continued remain strained. Pramod felt that Tarun was not giving him enough respect and did not appreciate the value of his experience. Tarun felt that his father was old-fashioned and does not want to hand over the controls.

Both of them, occasionally did appreciate the contribution of the other, but soon drifted into the criticism of the style and approach of each other.

Tarun got married in 2004 and within next three years wanted to live separately. Pramod was very sad with this demand. He believed that this signaled his failure as a father and separate house will eventually lead to separation in business. He kept on avoiding the demand on the excuse of not having adequate liquidity. They stayed together but with constant tensions between both of them.

By now Pramod has reduced his involvement in the business and Tarun is running the business. Pramod keeps overseeing the finance and HR aspects of the business which in Tarun's opinion are the worst managed departments and bottlenecks in the company's growth. On the other hand he does not want to take over the responsibilities as he believes that he is overloaded and he will not be able to handle more load.

Tarun feels that it is because of his father's adamant approach that he is not able to grow the business. Often he laments that instead of joining the family business if he had started something on his own, perhaps he would have grown much more in life.

\section{LEARNING OBJECTIVE}

The case has five primary learning objectives:

1) To understand the dynamics of the induction process in family managed businesses.

2) To understand the desired outcome of effective induction process in terms of its positive impact on the a) Business, b) Family relationship and c) Individuals involved.

3) To understand the impact of the inductee's willingness to join the business. 
4) The impact of the inductee's temperament.

5) The impact of the skills in managing tensions.

\section{USE OF THE CASE}

The case will fit well in the course in Organizational Behavior and the course in Family Business dynamics.

It can be used in the form of discussion. The discussion can be supplemented by a role play in which the role of father and son is played by two participants. Initially they individually speak to the audience about their concerns and then they are confronted against each other. The actors are free to create arguments beyond the facts given in the case but within the framework of the climate established. The class can give recommendations to the players and they may instantly respond with imaginative arguments.

The class will observe that each side has its own story and it is not easy to apply simple recommendations. They would notice the challenges of interpersonal dynamics magnified in the context of family business. They would realise the importance of effective induction process in the absence of which there is big damage to the business, family and the individuals.

\section{PREPARING FOR CLASS DISCUSSION}

Students should read the case and come to the class prepared to discuss the following questions?

1) Describe the situation of Pramod and his dilemmas. What happened in the induction process from his perspective?

2) Describe the situation of Tarun and his dilemmas. What happened in the induction process from his perspective?

3) Discuss the relationship between Pramod and Tarun as it would have started and how it evolved. What could be the factors responsible?

4) What could be the critical factors in the process of induction?

5. ORGANIZING DISCUSSION (assuming 90 minutes class)

I. Introduction. Importance of induction and the issue of dynamics. (10 minutes)

II. Diagnosis : Discuss the situation of Pramod (10 minutes)

III. Diagnosis : Discuss the situation of Tarun (10 minutes)

IV. Diagnosis : Discuss the relationship between Pramod and Tarun (10 minutes)

V. Role play : individual expression and confrontation (30 minutes)

VI. Recommendation : Discuss the critical factors in induction process (15 minutes)

VII. Conclusion ( 5 minutes)

\section{TEACHING THE CASE: BRIEF OVERVIEW OF ANALYSIS AND DISCUSSION}

This teaching plan is designed for a 90 minutes class session. This note presents the diagnosis of the relevant issues and explores possible recommendations. 


\section{ANALYSIS}

Instructor can open the class with a statement such as:

This is a case in which we will really get to explore the inter-personal challenges particularly in the context of family managed business and within that also the process of induction of the next generation member.

Family business has a unique context in which the two system of family and business overlap. The first generation businessman starts the business and has tremendous emotional attachment to the business. He has a particular way of working and believes that it is the only appropriate way of working. It works well when the founder is working himself alone.

There arises a serious challenge the moment anyone not from the system arrives on the scene. It could be a non-family employee or a family member. In the case of the former, there is an exit option available to both the sides and as such the challenge is comparatively lower. But in the case of family member, specifically from the next generation entering the business, unique challenges arise.

In this case, Pramod has started the business and his son Tarun has entered in the business few years back. Let us discuss your diagnosis of the situation.

\section{DIAGNOSIS - DISCUSS THE SITUATION OF PRAMOD}

Pramod did not inherit business from his father. He learned about the polymer business from his uncle and started the business, initially with trading and eventually set up his own unit in 1985.

A self-made man, as Pramod was, he is likely to have his own success formula for doing the business. He has worked hard. He has worked hands on with extensive grasp of the customers' needs. He seems to have developed new products that gave advantage to his firm and continues to save the day. Having set up the unit on his own obviously he did not have large resources and had got involved in all aspects of operations. That gave his excellent grasp of all aspects of business. The people whom he hired seem to respect him for his abilities and as a team the organization grew rapidly.

Over the years Pramod has developed tremendous amount of tacit knowledge and it is reflected in the growth of his business. He believes that in this business it is important to be hands on. In his opinion that is the trick of having an overall grasp on all aspects of business as well as securing respect from the employees.

Pramod is eager to get his son Tarun involved in the business. He would have liked Tarun to work like him. He would like to Tarun to get down in details and develop a grasp on the fundamental drivers. He would want Tarun to work hard and take up responsibilities.

Unfortunately for him, he found that Tarun was not putting appropriate efforts and as such avoided giving him free hand. 


\section{DIAGNOSIS - DISCUSS THE SITUATION OF TARUN}

Tarun was not good at studies. It is likely to have affected his self-image. He was showing no interest in the family business. In fact he had scant regard for that business treating it to be very small. He was over-confident about himself thinking that he can start something of his own and make it very big. He did not seem to have any foundation for this belief but seemed to be obsessed with that idea resulting in his taking no interest in family business.

He tried a venture and failed. That also is likely to have worked on his self-image. Eventually he decided to join the family business at the age of 22 . He did not have any idea about polymers. He started attending the office but had no clear responsibilities. He was critical of his father's way of working. He felt that his father was getting involved in too much niti-grity instead of appointing competent people and delegating the work.

His father would advise him to take more responsibilities but he avoided the same blaming his father's style of working. He felt strangled under his father, would like to have free hand in running the business, but his father would not give him free hand.

Over the years he did get more involved in the business and started taking responsibilities. He seemed to have a demanding style because of which many old employees left the organization. He did not have much firsthand experience in the business and as such could not come up with any innovation.

He was unhappy with his father. He felt that his father was old-fashioned and did not want to hand over the controls of the business. He believed that because of his father's adamant approach he is not able to grow the business.

In the Indian joint family system it is common that after marriage the son and his wife stay with his parents. However within 3 years of his marriage he wanted to separate from the parents and stay separately. This is not a very welcome situation in Indian context and is considered as a failure in learning to live together.

\section{DIAGNOSIS - DISCUSS THE RELATIONSHIP BETWEEN PRAMOD AND TARUN}

This is case of induction of the next generation in the family business. The son, Tarun is inducted in the business. However the induction is not effective

- In terms of effect on the business - the business has grown but the profitability has declined. No new innovation has taken place and the old key employees have left.

- In terms of family - the relation between father and son are strained. Father is unhappy with the performance of the son as he did not come up to his expectation. He believes that he is not getting the respect form his son that he deserves and he is not confident about the future on the business in the hands of his son. The son is unhappy with father, blaming him for not giving him full controls. He believes that it is because of his father's adamant approach that he could not grow the business. He wanted to stay separate from 
his father, which in Indian context is considered as an outcome of strong tensions between the father and son.

- In terms of impact on the individuals involved - Both father and son are unhappy. Father Pramod is unhappy as he is facing tensions with his son and at the same time is witnessing the downslide of the business created by him. The son, Tarun, is not happy and often feels that he would have been better had he started something of his own.

\section{IMPACT OF THE WILLINGNESS TO JOIN THE BUSINESS}

Tarun, the son has joined the business reluctantly. Perhaps his lack of enthusiasm and reservations from beginning could have led to the failure of the induction process.

He did not want to join his father's business and he did not take much interest in that. Eventually he joined the business but did so reluctantly. He tried to start a separate venture and only when he could not succeed in that venture, he joined the father's business. On joining the business he did not put in much hard work and believed in just delegating the work. Rather he was critical of his father's hands on business style. He did not develop good grasp of the business. He could maintain the business but could not come up with new initiative and innovations to make quantum jump in the business.

The father seem to have wished that his son get involved into the business but did not seem to have done anything from the young age of the son to get him excited to join the family business. He also did not seem to have any structured induction plan.

Father and son are working together for over 15 years now. They are unhappy with each other. Though occasionally they admit about each other's contribution yet immediately they slide into the mutual criticism. Their relations are strained.

\section{IMPACT OF INDUCTEE'S TEMPERAMENT}

Tarun, the inductee was not good at studies. He somehow completed his graduation. Yet he was overconfident. He believed that his father's business was very small and that he will start a new business and make it very big.

He did not take much interest in the family business and was complaining about his father's style. Despite his father advising him many times to get involved into the details, he did not do that and instead criticized his father for being over involved into the nity-grity of the business. It is evident that he was overconfident and did not pay much attention to the details. He did not have much grip on the business. There was a constant tension with his father and they ended up with minimal communication.

On one hand he is critical of the way his father is handling the portfolio of HR and Finance function. On the other hand he does not want to take over the responsibilities claiming to be overloaded. 


\section{IMPACT OF SKILLS IN MANAGING THE TENSIONS}

In inter-personal relationship the ability to handle the tensions is critical. In this case, Tarun joined the business at the age of 22. Initially he did not take much responsibility He felt that his father did not give him free hand. There was tension between the two and eventually they avoided facing each other and had minimal communication. That reflects lack of the abilities on both the side to handle the conflicts. The father was unhappy at the attitude of the son of not going in the details which in other words means that he did not have confidence in son's abilities and the son was unhappy with his various aspects of his father's approach.

\section{ROLE PLAY : INDIVIDUAL EXPRESSION AND CONFRONTATION}

As discussed above, in the role play the role of father and son is played by two participants. Initially each of them speaks to the audience about their concerns and later they are confronted against each other. The actors are free to create arguments beyond the facts given in the case but within the framework of the climate established. The class can give recommendations to the players and they may instantly respond with imaginative arguments.

The class will observe that each side has its own story and it is not easy to apply simple recommendations. They would notice the challenges of interpersonal dynamics magnified in the context of family business. They would realize the importance of effective induction process in the absence of which there is big damage to the business, family and the individuals.

\section{RECOMMENDATION: DISCUSS THE CRITICAL FACTORS IN INDUCTION PROCESS}

From the discussions so far, we could identify some of the critical factors. The listing can't be exhaustive and all factors may not be applicable in all situations. Yet it could be indicative;

1) Induction process affects business, family relations as well as both the parties personally.

2) Willingness and enthusiasm of the inductee to join the family business could affect the outcome of the induction process.

3) There can be disagreements between father and son. But mutual respect and openness to each other is required to resolve the issues.

4) The father has acquired tacit knowledge over the years. The son should respect the father for having developed the business and should be receptive to acquire the tacit knowledge from the father. That requires being with the father and observing him handling the situations. In this case with their inability to handle the tensions, the father and son started avoiding each other, whereby all possibilities of transfer of tacit knowledge vanished.

5) It is important for the inductee to have humility and willingness to learn. He also needs the attitude of doing hard work and going into details.

6) A systematic induction plan from young age could facilitate a good induction process. 


\section{CONCLUSION}

Inter-personal relations are important. Skills in managing the same, is required in all aspects of life and business. In Family business the two systems of family and business operate concurrently and that adds complexity to the issue of inter-personal relations.

Induction of the next generation member into the business is one area where the issue becomes even more critical. The effectiveness of managing the induction smoothly has serious eventual impact on the business, family relations and the life of all individuals concerned. 